\title{
IDENTIFIKASI KEBUTUHAN LAYANAN PERPUSTAKAAN SAINS DAN TEKNOLOGI NUKLIR BERBASIS INKLUSI SOSIAL
}

\author{
Hadi Susilo ${ }^{1}$, Noeraida ${ }^{2}$ \\ 1,2 Direktorat Repositori, Multimedia dan Penerbitan Ilmiah \\ Badan Riset dan Inovasi Nasional Jakarta \\ E-mail: hadi.susilo@brin.go.id; noeraida@brin.go.id
}

\begin{abstract}
Abstrak
Pemerintah saat ini menggalakkan layanan perpustakaan berbasis inklusi sosial. Perpustakaan Sains dan Teknologi Nuklir sebagai perpustakaan khusus, dapat berperan dalam memberdayakan pemustaka dalam konteks inklusi sosial agar produk yang dihasilkan oleh peneliti dapat bermanfaat bagi masyarakat luas. Selain itu, yang utama adalah untuk meningkatkan keberterimaan, masyarakat awam terhadap iptek nuklir melalui layanan perpustakaan berbasis inklusi sosial sangat tepat. Tujuan dalam makalah ini adalah untuk mengidentifikasi kebutuhan layanan perpustakaan berbasis inklusi sosial. Metode yang digunakan adalah deskriptif analisis dengan pengumpulan data dari literatur dan dokumen ilmiah produk hasil penelitian bidang iptek nuklir. Berdasarkan hasil dan pembahasan, terdapat beberapa tahap yang harus dilakukan pustakawan yaitu mengembangkan layanan perpustakaan dengan mengidentifikasi pengguna, pengembangan koleksi, kelembagaan dan layanan, kajian kelayakan teknis dan operasional serta upaya yang dilakukan saat ini. Beberapa upaya yang harus dilakukan pustakawan yaitu dengan melakukan penataan fisik, Inventarisasi, identifikasi dan pemilihan koleksi, melakukan kemas ulang koleksi, melakukan jejaring perpustakaan. Konsep layanan inklusi sosial yang dapat dilakukan dengan memberikan layanan Internal kepada keluarga pegawai dan selain pegawai seperti cleaning services melalui ceramah atau pelatihan. Selain itu layanan eksternal dengan mengundang tokoh untuk memperoleh informasi megenai kebutuhan masyarakat agar dapat memberikan pelatihan yang sesuai dengan kebutuhan. Dapat disimpulkan bahwa pustakawan pada perpustakaan sains dan teknologi nuklir sangat perlu melakukan layanan perpustakaan inklusi sosial agar produk iptek nuklir bermanfaat secara optimal dan dapat diterima secara positif oleh masyarakat luas.
\end{abstract}

Kata Kunci: identifikasi kebutuban, layanan perpustakaan, inklusi social, pengembangan perpustakaan

\begin{abstract}
The government is currently promoting library services based on social inclusion. The Nuclear Science and Technology Library as a special library can play a role in empowering users in the context of social inclusion. The products by researchers can be useful for the society, and to increase public acceptance of nuclear science and technology. The purpose of this paper is to identify the need for social inclusion-based library services. The method used is descriptive analysis by collecting data from literature and scientific documents of research products in the field of nuclear science and technology. The results, several stages that must be carried out by librarians, namely developing library services by identifying users, developing collections, institutions and services, technical and operational feasibility studies as well as current efforts. Efforts that must be made by librarians, namely by doing physical arrangement, inventory, identification, selection of collections, repackaging collections, conducting library networks. The concept of social inclusion services that can be done by providing internal services to employees' families and non-employees such as cleaning services through lectures or training. External services are invited by inviting leaders to obtain information regarding the needs of the community so that they can provide training according to their needs. Conclusion that librarians in nuclear science and technology libraries really need to provide social inclusion library services so that nuclear science and technology products are optimally useful and can be received positively by the wider community.
\end{abstract}

Keywords: identification, library services, social inclusion, library development 


\section{PENDAHULUAN}

Peran Perpustakaan Khusus Berbasis Inklusi Sosial untuk Generasi Digital Indonesia yang disampaikan pada seminar pada tanggal 31 Juli 2019, Agus Rusmana menyatakan bahwa masyarakat inklusif sosial atau masyarakat normal adalah yang cukup atau lebih secara finansial, fasilitas, mampu menjangkau fasilitas dan memiliki strata sosial yang cukup. Sebaliknya, masyarakat yang ekslusif sosial adalah masyarakat yang dibawah normal seperti masyarakat yang mempunyai kekurangan, antara lain seperti kaum disabilitas, ekonomi rendah, dan lain-lain (Rusmana, 2019). Perpustakaan dan Pustakawan dapat berperan dalam transformasi masyarakat ekslusif menjadi inklusif dalam kehidupan sosial. Dalam konteks ini, ada 2 (dua) tugas Pustakawan yakni: pertama membuat agar Perpustakaan dapat dikunjungi secacara fisik dan dimanfaatkan oleh semua orang. Kedua memberdayakan masyarakat, terutama yang berkebutuhan khusus dengan tujuan supaya memiliki pengetahuan dan kemampuan seperti masyarakat normal (inklusif).

Selanjutnya pada siaran pers dari Kementerian Perencanaan Pembangunan Nasional Bappenas, (2018), menyatakan bahwa pemerintah sedang mencanangkan program Kebijakan Transformasi Perpustakaan Berbasis Inklusi Sosial. Paradigma masyarakat terhadap perpustakaan harus diubah bukan hanya sebagai kolektor buku dan karya tulis yang tertata di rak-rak pajangan. Dalam konteks ini, perlu dilakukan transformasi layanan Perpustakaan yang berbasis inklusi sosial, yakni suatu pendekatan pelayanan Perpustakaan yang berkomitmen meningkatkan kualitas hidup dan kesejahteraan masyarakat pengguna. Inklusi sosial merupakan pendekatan berbasis sistem sosial yang memandang Perpustakaan sebagai sub sistem sosial dalam kemasyarakatan.
Menurut Suharyanto Mallawa (2019), pembelajaran sepanjang hayat merupakan kata kunci dalam pengembangan transformasi Perpustakaan berbasis inklusi sosial. Perpustakaan selain sebagai pusat informasi dapat menjadi tempat pengembangan diri masyarakat sehingga dapat meningkatkan kesejahteraan masyarakat.

Berdasarkan uraian tentang transformasi Perpustakaan berbasis inklusi sosial tersebut, yang dapat memberikan layanan langsung kepada masyarakat sampai tingkat kelurahan adalah Perpustakaan Umum yang berada dalam pembinaan Pemerintah Daerah setempat. Namun pada Undang-undang Republik Indonesia Nomor 43 Tahun 2007 tentang perpustakaan pada pasal 26, 27 dan 28 menjelaskan bahwa Perpustakaan Khusus dapat memberikan layanan kepada pemustaka di lingkungannya dan secara terbatas memberikan layanan kepada pemustaka di luar lingkungannya. Diselenggarakan sesuai Standar Perpustakaan Nasional, dan Pemerintah Daerah memberikan bantuan pembinaan teknis pengelolaan dan atau pengembangan perpustakaan kepada Perpustakaan Khusus. Berdasarkan pasal-pasal tersebut, Perpustakaan Khusus juga mempunyai kewajiban dan peluang untuk memberikan layanan kepada Pemustaka di luar lingkungannya.

Badan Tenaga Nuklir Nasional (BATAN) yang saat ini menjadi Organisasi Riset Tenaga Nuklir (ORTN) yang telah bergabung ke dalam Badan Riset dan Inovasi Nasional (BRIN) memiliki perpustakaan khusus untuk mendukung para pelaku Litbangjirap terhadap kebutuhan literatur. Sebagai institusi pelaksana litbangjirap dalam ranah sains dan teknologi nuklir yang memiliki visi dan misi dalam melakukan hilirisasi hasil litbangjirap sains dan teknologi nuklir kepada masyarakat luas. Hal ini dapat diterapkan secara produktif 
dalam berbagai aspek kehidupannya. Hingga saat ini, BATAN telah menghasilkan litbangjirap iptek nuklir di berbagai bidang kehidupan, meliputi Kesehatan, Pertanian, Peternakan, Lingkungan Hidup, dan berbagai aplikasi di bidang industri seperti pengujian kualitas bahan dan pengawetan material komponen produk manufaktur, sterilisasi alat kesehatan dan bahan makanan.

Hasil-hasil litbangjirap iptek nuklir tersebut, sebagian besar berpotensi dan dapat dimanfaatkan oleh para pihak di dalam negeri untuk peningkatan nilai ekonomi dan kesejahteraan masyarakat. Hasil litbangjirap iptek nuklir yang dihasilkan bangsa Indonesia, bahkan telah diakui dunia internasional melalui pengakuan organ PBB yang menangani energi nuklir yakni IAEA (International Atomic Energy Agency) sehingga juga telah direkomendasikan untuk pemanfaatannya oleh Negara lain di seluruh dunia. Produk litbangjirap iptek nuklir perlu dikelompokkan berbasis kemamputerapannya oleh berbagai kelompok masyarakat, meliputi para pengguna ahli (expert users), organ regulator dan penentu kebijakan, serta masyarakat umum selaku pengguna awam (novice users).

Hasil litbangjirap yang dihasilkan BATAN meliputi berbagai hal terkait penerapan sains dan teknologi nuklir, mulai dari yang masih bersifat dasar (teoritis) dan eksperimental (dalam skala laboratorium), wujud purwarupa (prototype). Hal tersebut telah siap untuk dilakukan peningkatan, penerapan secara komersial ke dunia industri, hingga tahapan lanjut dan siap pakai oleh masyarakat sebagai pengguna akhir. Sementara itu, untuk pengelolaan aset pengetahuan organisasi, Pustakawan selaku pekerja pengetahuan (knowledge worker) perlu berperan dalam pengorganisasian produk litbangiirap seperti ini.
Proses pengorganisasian produk litbangjirap yang dimaksud, selain perlu disesuaikan dengan kaidah kepustakawanan saat dikoleksi sebagai bahan pustaka di Perpustakaan, perlu diarahkan dan direlasikan dengan para penggunanya dalam konteks sebagai Pemustaka. Organ Perpustakaan, termasuk Perpustakaan kategori khusus seperti Perpustakaan Sains dan Teknologi Nuklir yang dikelola BATAN, yang keberadaannya secara regulatif mendapat prioritas peran dalam memberdayakan masyarakat, seperti telah diatur dalam Undang-Undang Republik Indonesia Nomor 43 Tahun 2007 tentang Perpustakaan, perlu lebih terpanggil dan mengedepankan perannya untuk berkontribusi dalam memberikan solusi terhadap berbagai masalah kehidupan dengan cara memberdayakan masyarakat terkait.

Berdasarkan latar belakang, alur pikir dan penalaran logis yang sudah diuraikan sebelumnya, pembuatan makalah ini adalah merupakan proses identifikasi masyarakat pengguna selaku Pemustaka dan kemudian merelasikan kebutuhan layanan yang cocok untuk memenuhi kebutuhannya. Oleh karena itu diperlukan sebuah rencana pengembangan layanan perpustakaan teknologi nuklir berbasis inkusi sosial agar hasil produk iptek nuklir dapat memberikan mafaat dan meningkatkan kesejahteraan kepada masyarakat luas.

Tujuan dalam makalah ini adalah mengidentifikasi kebutuhan layanan perpustakaan dengan menawarkan suatu model dengan mengembangkan layanan perpustakaan sains dan teknologi nuklir berbasis inklusi sosial. Pengembangan layanan tersebut dijabarkan dalam beberapa rencana layanan perpustakaan dengan melakuka beberapa tahap kegiatan yaitu:

1. Identifikasi Pengguna

2. Rencana Pengembangan koleksi 
3. Rencana Pengembangan Kelembagaan dan Layanan

4. Kajian Kelayakan Teknis dan Operasional

5. Upaya yang dapat dilakukan saat ini

\section{METODE KAJIAN}

Makalah ini merupakan gagasan, tinjauan, kajian, dan penalaran ilmiah tentang pengembangan layanan Perpustakaan Sains dan Teknologi Nuklir berbasis inklusi sosial dengan tujuan pemberdayaan masyarakat dalam konteks sebagai pengguna layanan (Pemustaka). Metode penulisan menggunakan metode deskriptif analitis, yaitu sebuah metode yang memaparkan objek yang akan dikaji untuk menghasilkan sebuah gambaran berdasarkan data apa adanya tanpa bermaksud membuat sebuah kesimpulan yang berlaku untuk umum atau generalisasi (Sugiyono, 2012). Adapun pengumpulan data diperoleh melalui identifikasi kebutuhan perpustakaan untuk memberikan layanan perpustakaan inklusi social baik dari literatur yang diakses dari jurnal melalui internet maupun koleksi yang dimiliki perpustakaan.

\section{Pengembangan Layanan Perpustakaan Berbasis Inklusi Sosial}

Layanan perpustakaan pada perpustakaan khusus instansi pemerintah selama ini adalah memberikan layanan bagi yang membutuhkan literatur dan akses informasi untuk mendukung kinerja para pegawai di instansi induk selain juga pemustaka dari luar instansi yang berkunjung ke perpustakaan (Noeraida, 2017). Namun untuk dapat memberikan layanan bagi masyarakat sekitar di luar lingkungan instansi, dapat dilakukan dengan memberikan layanan prima, yaitu layanan yang dilakukan secara proaktif, yang dapat membantu individu dan masyarakat untuk mengembangkan keterampilan dan kepercayaan diri serta membantu meningkatkan jejaring social (Haryanti, 2019).
Perpustakaan berbasis inklusi sosial adalah Perpustakaan yang dapat memberikan fasilitas kepada masyarakat untuk mengembangkan kemampuannya atau potensinya tanpa melihat perbedaan budaya, agama dan lainnya dengan memberikan kesempatan untuk memiliki keterampilan yang praktis yang dapat meningkatkan kesejahteraannya. Inklusi sosial adalah cara atau pendekatan untuk meningkatkan kualitas hidup masyarakat pada sebuah lingkungan untuk lebih baik dengan meningkatkan martabat dengan memberikan keterampilan kepada individu agar dapat menjadi pribadi yang mandiri sebagai modal utama. Masyarakat diikutsertakan dengan tidak melihat perbedaan yang ada (Khairunisa, 2020).

Untuk dapat memberikan layanan perpustakaan berbasis inklusi sosial, yang utama harus dipersiapkan adalah penyediaan koleksi dalam bentuk digital, dikelola dan dapat diakses secara bersamaan dan berjenjang dalam suatu sistem otomasi perpustakaan. Terdapat 10 jalur yang menurut Khairunisa (2020) dapat dikembangkan untuk layanan perpustakaan berbasis inklusi sosial pada era digital yaitu:

1) Koleksi digital.

Perpustakaan harus siap untuk koleksi "digital plus", termasuk didalamnya produk yang born digital dan kemudian diproduksi sebagai aneka produk, cetak maupun non cetak.

2) Jaringan.

Harus ada jaringan yang berskala luas agar dapat digunakan secara meluas pula. Jaringan antar perpustakaan amat penting. Bukan hanya antar perpustakaan, tetapi juga dengan berbagai isntitusi serupa, seperti museum, pusat arsip, pusatpusat kebudayaan, dan lain sebagainya.

3) Layanan sesuai kebutuhan masyarakat. 
Harus ada pemahaman ulang yang komprehensif tentang layanan yang sesuai kebutuhan masyarakat, sehingga kedekatan dan aliansi dengan komunikasi lokal menjadi seseuai yang mutlak.

4) Ruang fisik.

Perpustakaan tetap memerlukan ruangan fisik, terutama untuk kesan terbuka secara demokratis, walau pun juga menyediakan fasilitas ruang maya.

5) Layanan umum.

Perpustakaan harus tetap mengutamakan layanan yang berdasarkan "kepentingan umum".

6) Kerjasama.

Kerjasama dengan pengarang dan penerbit menjadi semakin penting.

7) Labolatorium.

Perpustakaan harus neyediakan ruang-ruang coproduction facilities, semacam laboratorium bertemunya orangorang yang seminat.

8) Pustakawan.

Pustakawan dan ahli-ahli teknologi informasi semakin perlu bekerjasama.

9) Pelestarian.

Pelestarian pengetahuan juga memerlukan kerjasama para pihak terkait.

10) Dana

Seiring dengan banyaknya produk litbangjirap iptek nuklir yang dihasilkan oleh para peneliti, perlu dibarengi dengan mengenalkannya ke para pihak, terutama para pembuat kebijakan publik di tingkat nasional dan daerah, pengguna dan calon pengguna potensial, serta masyarakat luas. Hal yang perlu diperhatikan adalah produk litbangjirapjirap kenukliran yang bernilai tambah dan sangat bermanfaat untuk kesejahteraan masyarakat, di sisi lain para penentu kebijakan publik belum sepenuhnya mendukung pemanfaatannya secara formal dan masif. Disamping itu, pemahaman masyarakat terhadap iptek nuklir juga belum memadai, termasuk pemahaman yang belum berimbang antara sisi manfaat dan kemungkinan dampak negatif penggunaan iptek nuklir. Hal ini dapat terjadi karena budaya membaca masyarakat yang masih relatif rendah, ditambah sebagian masyarakat menganggap bahwa pengetahuan nuklir hanya untuk kalangan tertentu saja.

Tujuan pemberdayaan masyarakat, dalam konteks penyelenggaraan kepustakawanan, untuk dapat memperbesar nilai tambah dari pemanfaatan hasil litbangjirapjirap iptek nuklir dan meningkatkan keberterimaannya, perlu dilakukan berbagai upaya seperti digambarkan dalam Gambar 1 berikut:

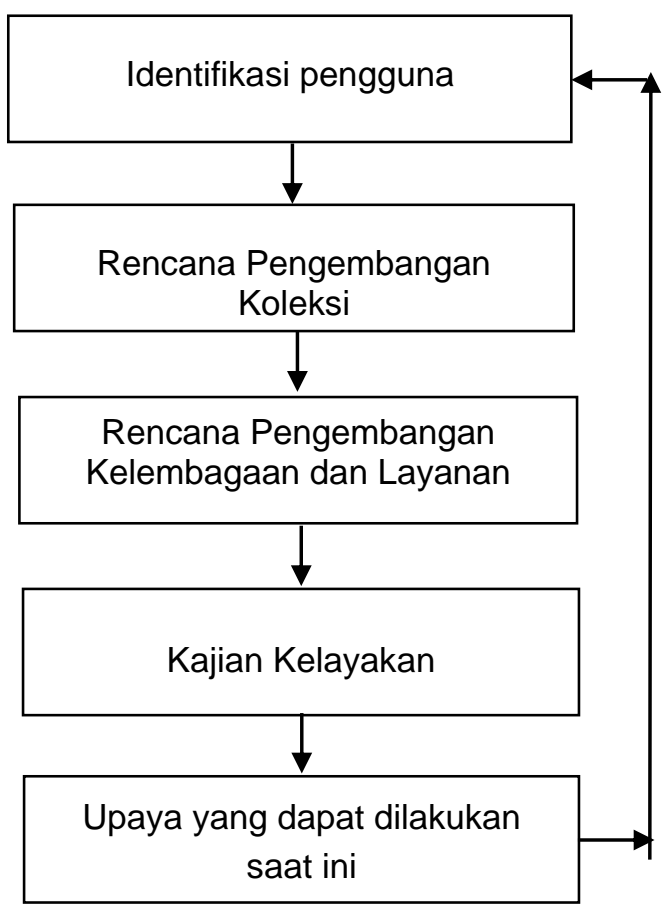

Gambar 1 Siklus pengembangan model pemberdayaan masyarakat dengan Perpustakaan Sains dan Teknologi Nuklir

Penerapan layanan perpustakaan berbasis inklusi sosial dapat dilakukan dengan mengembangkan sebuah rencana layanan perpustakaan bidang iptek nuklir dengan melakukan indentifikasi kebutuhan melalui 5 tahap kegiatan. 


\section{Identifikasi Pengguna.}

Pada langkah awal, harus dilakukan mengidentifikasi atau pendataan pemustaka dan prospeksi masyarakat yang berpotensi menjadi pengguna koleksi bahan pustaka. Selain seluruh Pegawai ORTN dan Organisasi Riset yang tergabung dalam BRIN, para pelaku litbangjirapjirap iptek nuklir juga meliputi seluruh Pejabat Fungsional terkait perlu menjadi target sebagai Pengguna. Pejabat Fungsional tersebut antara lain: Pengembang Teknologi Nuklir, Pranata Nuklir, Peneliti, Perekayasa, Dosen, Widyaiswara, dan Guru. Para Profesional dari kalangan Ahli Medis (Dokter, Paramedis, Perawat); Ahli Teknik (Insinyur, Teknisi); Ahli Radiografi (Radiografer, Operator pesawat sinar $\mathrm{X}$ ); Pendidik/Pengajar (Guru, Instruktur, Pelatih); Farmer (Petani, Peternak, Nelayan) juga perlu dijadikan target pengguna.

Selanjutnya, mengingat perannya yang sangat menentukan, para penentu keputusan dan pembuat kebijakan publik harus secara proaktif dijadikan pengguna layanan. Komponen pengguna ini di tingkat nasional meliputi: Presiden; para Menteri; DPR; Badan Perencana, Pengkaji, Regulasi, dan, Pengawas (BAPPENAS, BAPETEN, DEN, OMBUDSMAN, KADIN); Organisasi Profesi (IDI, PII, PKNI, HKTI, dll.). Mengingat masalah nuklir juga merupakan isu internasional, penentu kebijakan ditingkat internasional juga perlu dijadikan pengguna, meliputi entitas dalam koordinasi PBB (IAEA, CTBTO, WHO, FAO, UNDP, UNESCO); lingkup otoritas Negaranegara mitra (OECD, CERN, JAEA, AECL, ANSTO, WNA, WNU, etc.); lingkup lembaga otoritas keuangan dunia (World Bank, IMF, ADB, IDB, etc.).

Kelompok generasi muda dari kalangan Pelajar dan Mahasiswa juga harus diupayakan menjadi pengguna aktif koleksi informasi dan pengetahuan nuklir. Demikian juga kelompok masyarakat yang berminat dan pemerhati iptek nuklir (Calon dan Pengusaha/ Investor Industri Nuklir, Pemerhati Lingkungan Hidup) juga perlu menjadi perhatian khusus. Masyarakat umum dari kelompok awam dan komunitas khusus (penderita penyakit/kanker, penyandang cacat) juga harus mendapat perhatian khusus dan secara proaktifbahkan dengan pendekatan personal perlu dijadikan pengguna penting mengingat perannya terhadap keberterimaan terhadap aplikasi teknologi nuklir untuk peningkatan taraf hidup dan kesejahteraan.

\section{Pengembangan koleksi.}

Setelah semua komponen masyarakat yang menjadi Pemustaka terdata dengan lengkap, tahap selanjutnya adalah membuat rencana pengembangan koleksi yang diawali dengan mendata semua bahan pustaka yang diperlukan oleh masing-masing Pemustaka secara khusus. Selanjutnya perlu mengkreasikan koleksi pustaka jenis baru seperti berbagai artefaks hasil litbangjirapjirap iptek nuklir seperti detektor/sensor radiasi, berbagai dokumen rencana bisnis (business plan) berbasis aplikasi iptek nuklir dan kontek kreatif yang lain. Selain konten koleksi yang beragam, dari sisi kemasan, juga perlu dilakukan pengembangan, terutama memperbanyak kemasan audio visual kreatif berbasis platform digital.

\section{Rencana Pengembangan Kelembagaan dan Layanan.}

Pada tahap ini, disusun strategi sistematis tentang pengembangan model kelembagaan dan layanan Perpustakaan Sains dan Teknologi Nuklir dengan tujuan utama memberikan nilai tambah kepada masyarakat. Dalam konteks kelembagaan perlu diarahkan menjadi National Nuclear Gallery, Library, Archives, 
and Museum of Indonesia (National Nuclear GLAM of Indonesia). Di sisi layanan, selain pola layanan terdahulu yang bersifat konvensional berupa peminjaman dan penggunaan koleksi bahan pustaka, perlu dikreasikan layanan On Demand Library Services (ODLS).

Layanan jenis ini, selain dapat disesuaikan dengan kebutuhan dan selera khusus para pengguna tertentu yang khas/spesifik sehingga dapat dilakukan penyesuaian (customized) dan bahkan bersifat personal. Kemasan layanan seperti ini dapat berupa tayangan video streaming tertentu dan kemasan digital kreatif yang lain. Bentuk layanan lain yang perlu ditawarkan oleh para Pustakawan adalah jasa konsultasi dan analisa data kepustakaan berbasis analisis bibliometrik.

\section{Kajian Kelayakan Teknis dan Operasional}

Tahap ini membahas berbagai hal terkait studi dan kajian untuk menilai kelayakan teknis dan operasional terhadap strategi atau rencana pengembangan model pemberdayaan masyarakat dengan Perpustakaan Sains dan Teknologi Nuklir yang telah disusun pada tahap sebelumnya. Hasil kajian ini, selanjutnya digunakan untuk menentukan upaya lanjutan guna praktek pengoperasian Perpustakaan Sains dan Teknologi Nuklir berbasis inklusi sosial.

\section{Upaya yang dapat dilakukan saat ini}

Pada bagain ini, diuraikan berbagai upaya kontributif yang dapat dilakukan untuk mendukung pemberlakuan layanan perpustakaan inklusi sosial yang dapat memberikan nilai tambah kepada masyarakat (Pemustaka). Beberapa rencana pengembangan layanan perpustakaan dijabarkan dalam tahapan kegiatan yang dapat dilakukan saat ini seperti ditampilkan pada Tabel 1.

\section{A. Penataan Fisik}

Langkah awal pustakawan adalah dapat melakukan upaya dengan menambahkan dan menyediakan fasilitas fisik, antara lain:

1. Melengkapi rambu-rambu yang kurang untuk membantu pemustaka dalam menemukan dan memanfaatkan koleksi serta fasilitas perpustakaan secara optimal. Adapun rambu-rambu yang diperlukan adalah: (a) rambu-rambu identifikasi untuk menunjukkan identitas atau label sebuah ruangan atau area koleksi; (b) rambu penunjuk arah berupa tulisan atau gambar perpustakaan yang dipasang dari luar gedung dan di depan pintu masuk perpustakaan, petunjuk arah ke toilet dan mushola; (c) rambu peringatan atau larangan seperti "dilarang merokok"; (d) rambu informasi seperti meja Informasi, lemari penitipan barang, dan lainnya (Luthfiati Makarim, 2014).

2. Melengkapi rambu-rambu yang kurang untuk membantu pemustaka dalam menemukan dan memanfaatkan koleksi serta fasilitas perpustakaan secara optimal. Adapun rambu-rambu yang diperlukan adalah: (a) rambu-rambu identifikasi untuk menunjukkan identitas atau label sebuah ruangan atau area koleksi; (b) rambu penunjuk arah berupa tulisan atau gambar perpustakaan yang dipasang dari luar gedung dan di depan pintu masuk perpustakaan, petunjuk arah ke toilet dan mushola; (c) rambu peringatan atau larangan seperti "dilarang merokok"; (d) rambu informasi seperti meja Informasi, lemari penitipan barang, dan lainnya (Luthfiati Makarim, 2014). 
Tabel 1. Identifikasi Kebutuhan Rencana pengembangan layanan perpustakaan

\begin{tabular}{lll}
\hline & Tahapan Kegiatan & Pelaksanaan kegiatan \\
\hline A & Penataan fisik & Membuat rambu-rambu: label, arah, peringatan, informasi \\
& & Membuat pintu masuk otomatis \\
& Membuat Iptek Nuklir Corner \\
\hline B $\quad$ Inventarisasi, & Inventarisasi kokelsi produk hasil itbangjirap \\
& identifikasi dan & Identifikasi kokelsi produk hasil itbangjirap \\
& Pemilihan koleksi & Pemilihan koleksi \\
& & Pengolahan koleksi \\
& Menata koleksi pada Iptek Nuklir Corner \\
\hline C & Mengemas ulang & Mengemas ulang buku atau brosur menjadi terbitan baru \\
& koleksi & Mengalihbentukkan buku dalam bentuk digital \\
& Menambah menu iNuklir pada perpustakaan digital \\
& Submenu produk hasil litbangiirap: pertanian, pengawetan, dll \\
& Mengupload buku versi baru ke iNuklir \\
& Mengalihbentukkan buku ke dalam huruf braille \\
& Membuat aplikasi digital iNuklir berbasis android \\
& Internal yaitu dengan: peneliti dan penerbit \\
& Direktorat Diseminasi dan Pemanfaatan Riset dan inovasi \\
& Daerah \\
& Direktorat Pemanfaatan Riset dan Inovasi pada Kementrian dan \\
& Lembaga dan UMKM \\
& Eksternal dengan Perpustakaan Nasional RI \\
\hline &
\end{tabular}

3. Membuat pintu masuk perpustakaan yang otomatis dapat terbuka sendiri sehingga kaun disabilitas dapat masuk tanpa meminta bantuan.

4. Menyiapkan area Iptek Nuklir Corner untuk menyimpan koleksi produk hasil litbangjirapjirap ORTN yang dapat dibaca di tempat baik dalam bentuk cetak maupun audio visual.

\section{B. Inventarisasi, identifikasi dan pemilihan koleksi}

Tahap selanjutnya adalah melakukan inventarisasi koleksi, yaitu melakukan pendataan dan pencatatan koleksi apa saja yang sudah dimiliki tentang produk hasil litbangjirapjirap yang sudah dihasilkan para peneliti baik dalam bentuk cetak maupun audio visual. Inventarisasi dilakukan untuk mengetahui jumlah, keberaadaan dan kelengkapan subjek dan jenis sumber informasi dari dan koleksi yang dapat diakses oleh pengguna. Selanjutnya dilakukan identifikasi koleksi dengan mengelompokkan koleksi untuk mengetahui potensi atau koleksi dan sumber informasi apa saja yang dimiliki oleh perpustakaan. Pengelompokan dan pemilihan koleksi sangat penting karena agar dapat membantu dalam mendiseminasikan iptek nuklir sesuai dengan produk yang sudah dihasilkan para peneliti.

Pemilihan koleksi dengan menyeleksi koleksi yang memiliki konten yang cocok dan bahasa yang lebih mudah dipahami oleh masyarakat yang awam terhadap iptek nuklir. Produk yang sudah antara lain dalam bidang energi, industri, lingkungan, kesehatan dan obatobatan, keselamatan dan keamanan, pertanian dan peternakan. Dalam model layanan perpustakaan inklusi sosial, produk litbangjirap yang tepat untuk memperkenalkan iptek nuklir kepada 
masyarakat adalah dalam bidang pertanian dan peternakan dan pengawetan. Hasil litbangjirap tersebut akan lebih mudah dipahami karena sering digunakan dalam kehidupan sehari-hari. Selain itu, dengan meningkatnya literasi masyarakat terhadap iptek nuklir.

Koleksi yang berkaitan dengan produk litbangjirap bidang pertanian yang sudah dihasilkan oleh para peneliti sejak tahun 1980 yaitu pemuliaan tanaman untuk meningkatkan ketahanan pangan melalui pengembangan aplikasi teknologi isotop dan radiasi, dengan berkontribusi terhadap pengkayaan jumlah varietas nasional. Dengan varietas unggul akan meningkatkan produktivitas, mempercepat waktu panen, tahan terhadap hama dan penyakit, serta keunggulan-keunggulan lainnya. Sampai dengan tahun 2017, litbangjirap iptek nuklir telah menghasilkan 20 varietas unggul padi sawah, 1 varietas unggul padi gogo, 10 varietas unggul kedelai, 2 varietas unggul kacang hijau, 1 varietas unggul kapas, 3 varietas unggul sorgum, 1 varietas unggul gandum, dan 1 varietas unggul kacang tanah (Badan Tenaga Nuklir Nasional, 2017).

Produk yang telah dihasilkan dalam bidang peternakan yaitu dalam pembuatan pakan, reproduksi, dan kesehatan ternak, seperti melakukan teknik jantanisasi pada ikan untuk memacu pertumbuhan/pembesaran ikan yaitu stimulant pakan ikan (SPI). Keunggulannya adalah dapat disimpan lebih lama dan tidak mengandung bakteri pathogen, lebih aman dikonsumsi dan harga menjadi lebih murah. Selain itu, di Indonesia tata kelola peternakan menunjukkan perkembangan yang membaik yang ditunjukkan dengan adanya SPR atau Sekolah Peternak Rakyat (Badan Tenaga Nuklir Nasional, 2018).

Hasil litbangjirap dalam bidang teknologi pengawetan dan sterilisasi menggunakan bahan kimia, pemanasan atau pendinginan telah lama dikenal masyarakat. Penggunaan pengawet tersebut berbahaya dan dapat mengakibatkan gangguan kesehatan seperti kesulitan untuk bernafas (asma), iritasi kulit, infeksi sistem pernafasan, kerusakan jantung, ginjal, leukemia, diabetes, dll. Dengan radiasi gamma yang dipancarkan dari unsur pemancar gamma dapat dimanfaatkan secara efektif untuk mengatasi permasalahan di bidang industri tersebut. Keunggulan yang dapat diperoleh antara lain dapat diproses dalam keadaan terkemas dan siap dipasarkan, dapat digunakan untuk produk dalam jumlah besar, target pemusnahan mikroba pada tingkat tertentu atau menyeluruh dapat dilakukan pada seluruh bagian produk, tidak menimbulkan kerusakan pada produk karena teknologi iradiasi merupakan proses dingin dan tidak menimbulkan residu bahan kimia. Pengawetan yang sudah dilakukan seperti untuk kosmetik dan rending atau pepes ikan. Adapun fasilitas iradiasi menggunakan sumber radiasi gamma diberi nama Irradiator yang telah dimiliki oleh BATAN dengan nama Irradiator Merah Putih yang berada di Serpong (Badan Tenaga Nuklir Nasional, 2020).

Sumber Informasi yang berasal dari contoh produk hasil litbangjirap yang dijelaskan tersebut dapat dijadikan koleksi untuk dikenalkan lebih dulu kepada masyarakat. Untuk memperoleh koleksi tentang tentang produk hasil litbangjirapjirap ORTN sampai saat ini diterbitkan oleh BATAN Press yang dikelola oleh Pusat Diseminasi dan Kemitraan (PDK). Oleh karena itu, perpustakaan harus bersinergi dan bekerjasama dengan PDK agar memperoleh koleksi yang lengkap baik dalam bentuk cetak, elektronik dan audio visual. Selain itu dapat juga diperoleh melalui perpustakaan digital batan https://digilib.batan.go.id/ dan repository 
institusi pada situs alamat http://reponkm.batan.go.id/.

\section{Mengemas ulang koleksi}

Berdasarkan hasil indentifikasi koleksi, selanjutnya koleksi dikelola sesuai dengan prosedur mulai dari inventarisasi, katatalogisasi, klasifikasi dan diinput ke pangkalan data. Pustakawan dapat bekerjasama dengan peneliti untuk mengemas ulang buku atau brosur menjadi terbitan baru yang lebih menarik dan mudah dicerna oleh masyarakat awam. Selanjutnya bekerjasama dengan penerbit untuk menerbitkan koleksi dalam bentuk cetak Agar koleksi mudah untuk diakses bagi pemustakaan yang datang ke perpustakaan, penataan, koleksi dalam bentuk cetak tersebut ditata di ruang terbuka dengan desain khusus yang menarik misalnya Iptek Nuklir Corner (Pojok Pustaka Nuklir). Penggunaan koleksi digunakan dalam sistem terbuka, bahkan koleksi dalam bentuk brosur dapat dibawa pulang oleh pemustaka.

Buku versi baru dikemas ulang ke dalam format elektronik/digital, dan di unggah ke website perpustakaan digital dengan menambahkan menu menu khusus seperti iNuklir (informasi Iptek nuklir) dengan submenu semua produk litbangjirap yang telah dihasilkan para peneliti. Tujuannya agar produk-produk litbangjirapjirap yang sudah dihasilkan seperti iptek nuklir dalam bidang pertanian, peternakan, dan pengawetan dan lainnya dapat diakses melalui internet. Jika iNuklir dapat dengan mudah diakses oleh pengguna, diharapkan dapat meningkatkan minat baca dan literasi masyarakat terhadap iptek nuklir.

Untuk layanan kepada masyarakat berkebutuhan khusus tunanetra, pustakawan dapat mengusulkan untuk mengalihbentukkan buku atau brosur yang sudah dikemas ulang ke dalam huruf Braille menggunakan printer khusus. Printer Braille (yang juga dikenal dengan istilah Braille embosser) digunakan untuk mencetak data yang dikirim dari komputer. Braille merupakan satu dari banyak produsen printer Braille di dunia. Printer ini banyak terdapat di Indonesia sebagai hasil kerjasama antara pemerintah Indonesia dan pemerintah Norwegia untuk mengembangkan pendidikan bagi tunanetra di Indonesia (Susanti, 2019). Saat ini sudah ada mesin cetak huruf Braille yang dirancang dan dikembangkan oleh Jurusan Teknik Elektro ITS. Hal ini merupakan salah satu kontribusi ITS dalam dunia riset dan teknologi (ristek), khususnya pada bidang manufaktur mesin cetak Braille dalam mendukung pendidikan inklusi (Dadang, 2014).

\section{iNuklir berbasis android}

Sesuai dengan perkembangan zaman, untuk meningkatkan minat baca masyarakat dapat dibuatkan aplikasi digital berbasis android yang dapat didownload di Playstore untuk Android, Appstore untuk iOS, serta PC. Aplikasi ijakarta yang telah dibuat oleh perpustakaan Dinas Perpustakaan dan Kearsipan DKI Jakarta bekerja sama dengan Aksaramaya. Selain itu ada iPusnas yaitu aplikasi perpustakaan digital yang simpel persembahan PNRI juga bekerja sama dengan Aksamaraya selaku pengembang aplikasi. Moto atau slogan yang menarik yaitu Membaca semakin mudah, baca buku, berbagi koleksi bacaan dan bersosialisasi secara bersamaan, tanpa dibatasi oleh ruang dan waktu dengan nyaman bersama setiap orang (PNRI, 2019). Melalui iPusnas, terdapat bermacam-macam e-book yang dapat dipinjam dan dibaca, dengan sistem peminjaman yang mudah dan ringkas oleh masyarakat dari semua kalangan. Pengguna agar dapat mengaksesnya hanya dengan melakukan registrasi, selanjutnya dapat meminjam buku untuk dibaca melalui gadget yang dimiliki. 
Demikian pula BRIN melalui Direktorat Repositori, Multimedia dan Penerbitan Ilmiah dapat membuat aplikasi digital sejenis yang berisi informasi tentang produk litbangjirapjirap yang telah dihasilkan oleh ORTN dengan nama khusus seperti iNuklir. Melalui aplikasi iNuklir, informasi tentang Batan dan iptek nuklir dalam sekejap akan berada dalam genggaman setiap orang. Masyarakat akan lebih mengenal iptek nuklir dan tidak awam dan tabu terhadap nuklir. Untuk dapat mewujudkannya diperlukan sinergi dan kerjasama antara perpustakaan dengan pejabat fungsional pranata komputer dalam membuat aplikasi. Adapun untuk konten bekerjasama dengan peneliti dan penerbit.

\section{Membangun jejaring perpustakaan}

Agar dapat meningkatkan layanan dengan koleksi yang memadai termasuk dapat mendiseminasikan produk iptek nuklir yang sudah dihasilkan ORTN, dapat dilakukan dengan membangun kerjasama antar perpustakaan inter library loan (ILL). Kegiatan ILL yang bisa menjangkau ke seluruh lapisan masyarakat adalah dengan PNRI. Butir kerjasama yang diharapkan adalah dapat memperoleh bantuan sarana dan prasarana seperti, bantuan pelatihan untuk peningkatan kompetensi untuk mengemas informasi iptek nuklir agar dapat menjadi salah satu koleksi dalam iPusnas. Agar dapat mengimplementasikan jejaring dan kerjasama ILL tersebut harus didahului dengan membuat $\mathrm{MOU}$ (memorandum of understanding) atau nota kesepahaman antara BRIN dengan PNRI.

Sementara itu, untuk mengenalkan dan meningkatkan minat baca masyarakat terhadap iptek nuklir di setiap daerah khususnya perpustakaan umum yang ada di setiap wilayah di
Indonesia, pustakawan mengirimkan buku atau brosur versi baru yang sudah dikemas ulang. Selanjutnya pustakawan menyelenggarakan pelatihan atau keterampilan singkat tentang produk Batan misalnya menanam padi yang sudah dimutasi genetiknya para peneliti bidang iptek nuklir. Hasil yang diharapkan setelah mengikuti pelatihan tersebut pengguna memperoleh tambahan pengetahuan dan keterampilan. Selanjutnya memiliki semangat untuk memulai berwirausaha yang akan menghasilkan pemasukan untuk meningkatkan kesejahteraannya.

Selain itu, dapat bekerja-sama dengan Badan Riset dan Inovasi Daerah (BRIDA) yaitu perangkat daerah yang menyelenggarakan litbangjirapjirap serta invensi dan inovasi yang terintegrasi di daerah. Melalui Direktorat Diseminasi dan Pemanfaatan Riset dan Inovasi Daerah pustakawan dapat bekerjasama untuk memberikan layanan inklusi social kepada masyarakat di daerah. Kerjasama dilakukan untuk menjadi sentral dan tempat untuk menyelenggaraan layanan perpustakaan inklusi sosial.

\section{Layanan Perpustakaan Inklusi Sosial}

Setelah melakukan tahapantahapan seperti pada Tabel 1, selanjutnya perlu dilakukan sosialisasi kepada masyarakat dan pengguna yang sesuai dengan tujuan layanan perpustakaan inklusi sosial. Meskipun sebelumnya ORTN sudah melakukan diseminasi iptek nuklir, namun untuk meningkatkan literasi tetap merupakan ranah dan salah satu program perpustakaan dan pustakawan. Perpustakaan harus mempunyai program layanan berbasis inklusi sosial yang dapat dilakukan untuk pengguna di lingkungan internal maupun di luar ORTN seperti dijelaskan dalam Tabel 2. 
Tabel 2. Konsep layanan perpustakaan iptek nuklir berbasis inklusi sosial

\begin{tabular}{lll}
\hline Layanan & Target pengguna & Pelaksanaan kegiatan \\
\hline Layanan & Dharma Wanita & Arisan menghadirkan narasumber \\
Internal & & Membuat FGD untuk identikasi kebutuhan \\
BRTN \& & & Pelatihan \\
\cline { 2 - 3 } & & Cleaning services dan \\
& pegawai outsourcing & Membuat FGD untuk identikasi kebutuhan \\
& Layanan di & Mengundang tokoh masyarakat \\
\hline Layanan & perpustakaan & Membuat FGD untuk identikasi kebutuhan \\
& & Pelatihan \\
\cline { 2 - 3 } & Layanan proaktif & Mengadakan kegiatan perpustakaan umum tingkat \\
& & kecamatan \\
& & Mengadakan kegiatan bekerjasama dengan PNRI \\
& & Mengirimkan koleksi ke yayasan tunanetra \\
\hline
\end{tabular}

\section{Layanan Internal}

Layanan internal dalam makalah ini dimaksudkan untuk memberikan layanan kepada keluarga besar pegawai ORTN seperti ibu-ibu Dharma Wanita (DW) yang belum mengetahui apa saja yang sudah dihasilkan oleh ORTN. Ibuibu DW seharusnya memiliki tanggungjawab moral untuk membantu ORTN dalam mensosialisasikan produk yang dihasilkan. Selain itu, Ibu-ibu merupakan orang-orang penting dan tepat yang dapat menyampaikan kembali kepada keluarga, tetangga, dan lainnya.

Layanan dapat diawali dengan membuah FGD (Forum Group Discussion) untuk melakukan sharing knowledge kebutuhan ibu-ibu DW dan menentukan program apa saja yang sesuai untuk dapat dilakukan untuk memenuhi kebutuhan tersebut. Selanjutnya dapat diimplementasikan kegiatan yang sudah disepakati misalnya mengadakan arisan secara bergiliran setiap unit kerja di Perpustakaan. Pada acara tersebut menghadirkan narasumber yang kompeten dengan nama acara bincang hasil litbangiirap iptek nuklir sekaligus mensosialisasikan aplikasi iNuklir, menyelenggarakan lomba menulis bebas tentang iptek nuklir.
Secara parallel dapat dilakukan identifikasi kebutuhan ibu-ibu DW untuk menyelengarakan pelatihan sesuai kebutuhan yang diharapkan dapat meningkatkan pengetahuan dan kesejahteraannya melalui produk litbangjirap yang sudah ada. Selanjutnya target diperluas ke Ibu-Ibu DW di lingkungan BRIN. Pola layanan yang sama dapat dilakukan dengan audiens pekerja outsourcing seperti dari kalangan cleaning services (CS) khususnya yang ada di lingkungan ORTN. Karena golongan ini termasuk dalam kelompok inklusi sosial. Selanjutnya target diperluas sampai ke CS dan OB di lingkungan BRIN.

\section{Layanan Eksternal}

Suatu perusahaan dalam menjalankan proses bisnisnya harus mempunyai corporate social responsibility (CSR) atau tanggung jawab social yaitu komitmen dengan berperan serta meningkatkan kualitas kehidupan dan kesejahteraan di lingkungan perusahaan, dan bagi masyarakat sekitarnya (Marnelly, 2012). Bagi lembaga pemerintah yang mempunyai tugas melakukan litbangjirap bidang iptek nuklir, juga harus mempunyai komitmen 
untuk melakukan CSR. Hal ini perlu dilakukan agar pemahaman masyarakat sekitar terhadap teknologi nuklir tidak hanya dipandang sebagai hal yang negatif, namun dapat dimanfaatkan untuk kesejahteraan masyarakat. Salah satu kegiatan yang sudah dilakukan setiap tahun oleh PPIKSN BATAN adalah bekerja sama Pusat Diseminasi dan kemitraan (PDK) BATAN adalah melaksanakan program Sarasehan bersama Tokoh Masyarakat di sekitar Kawasan Nuklir Serpong.

Adapun peserta yang diundang antara lain berasal dari 8 (delapan) Kecamatan dan Polsek, Koramil, Babinsa dan Babinkamtibmas dan dari 8 desa di sekitar Kawasan Nuklir Serpong, PMI Kabupaten Tangerang, BRI KCP. Muncul, DKM Bahrul Ulum serta tokoh masyarakat dari Kelurahan Muncul, Karangan, Baru Asih dan Sari Mulya. Selain itu juga program sosialisasi yang dikemas melalui sarasehan lainnya dengan mengajak peserta untuk melihatlihat secara langsung fasilitas reaktor nuklir, bekerjasama antara lain dengan Kota Tangerang Selatan, Kabupaten Tangerang dan Bogor dan sekitar lokasi BATAN.

Untuk memberikan layanan eksternal, pola yang sudah dilakukan oleh BATAN dapat diadopsi oleh perpustakaan dan pustakawan. Menyelenggarakan FGD untuk melakukan kegiatan seperti yang sudah dijelaskan sebelumnya. Implementasikan kegiatan yang sudah disepakati misalnya mengadakan pertemuan secara bergiliran untuk setiap kecamatan di perpustakaan, dan menghadirkan narasumber yang kompeten dengan nama acara bincang hasil litbangjirap iptek nuklir sekaligus mensosialisasikan aplikasi iBATAN. Menyelenggarakan lomba menulis bebas tentang iptek nuklir.

Beberapa contoh masyarakat yang telah dapat diberdayakan dengan produk litbangjirap iptek nuklir dapat dilihat pada tayangan audio-visual berikut:
1. Pembuatan tempe menggunakan Kemuning, Kedelai Mutan Tahan Kering yang merupakan produk hasil litbangjirap bidang pertanian dengan penjelasan pada link https://www. youtube.com $/$ watch? $\mathrm{v}=\mathrm{k} 2 \mathrm{RUN}$ Oneyd 4

2. Pengawetan rendang melalui iradiasi seperti dengan penjelasan pada link https://www.youtube.com/watch?v $=\mathrm{HgbwOLyeF}-0 \& \mathrm{t}=46 \mathrm{~s}$

3. Pembuatan supplemen pakan ternak superblok, salah satunya telah dimanfaatkan di Agro Techno Park (ATP) Polewali Mandar, Sulawesi Barat https:// www.youtube.com/watch?v $=\mathrm{t} 1 \mathrm{jkyv}$ Dea-4

4. Dalam bidang kedokteran: terapi paliatif penderita kanker dg radiofarmaka Sm-153 EDTMP https://www.youtube.com/watch?v $=$ oEug--vHDvM

\section{Layanan proaktif pustakawan untuk masyarakat sekitar}

Untuk melakukan layanan perpustakaan inklusi sosial, tidak cukup dengan mengundang masyarakat eksternal saja, namun harus melakukan layanan yang dilakukan secara proaktif ke masyarakat sekitar. Layanan ini dapat dilakukan dengan melakukan kerjasama, bermitra dan bersinergi dengan stakeholder, antara lain dengan perpustakaan Pemda terdekat. Agar dapat bermitra dengan perpustakaan umum pada tingkat kecamatan, harus diawali dengan membuat $\mathrm{MoU}$ antara BRIN dengan PNRI yang akan menjadi payung hukum untuk menjalin Kerjasama dengan unit kerja lain yang terkait.

Adapun pola layanan yang dilakukan adalah: mengadakan pertemuan di perpustakaan kota/kecamatan dan membentuk FGD; memberikan bantuan koleksi dan sumber informasi produk hasil litbangjirap iptek nuklir dalam 
bentuk cetak dan audio visual; mengadakan pertemuan yang diinisiasi oleh perpustakaan kota/kecamatan; mengimplementasikan kegiatan yang sudah disepakati misalnya mengadakan pertemuan bulanan dengan mengundang narasumber yang kompeten dengan nama acara bincang hasil litbangjirap iptek nuklir sekaligus mensosialisasikan aplikasi iNuklir. Secara parallel dapat dilakukan identifikasi kebutuhan dari peserta dan dapat diadakan pelatihan sesuai kebutuhan agar dapat meningkatkan pengetahuan dan kesejahteraannya melalui produk litbangjirap yang sudah ada.

Layanan proaktif untuk masyarakat berkebutuhan khusus tunanetra, perpustakaan mengirimkan koleksi yang sudah dialihbentukkan ke dalam huruf Braille ke sekolah luar biasa atau yayasan tunanetra. Selain itu juga koleksi audio visual tentang iptek nuklir juga dihibahkan. Untuk dapat memberikan layanan perpustakaan ke seluruh Indonesia, perpustakaan iptek nuklir dapat bersinergi dengan Perpustakaan Nasional yang sudah mempunyai jaringan yang lebih luas dan telah menerapkan layanan berbasis inklusi sosial.

\section{Kesimpulan}

Perpustakaan dan pustakawan pada perpustakaan khusus instansi pemerintah dapat berperan untuk meningkatkan kesejahteraan masyarakat dengan turut serta memberikan layanan perpustakaan inklusi sosial. Demikian pula perpustakaan sains dan teknologi nuklir yang dikelola oleh BATAN sangat penting untuk melakukan layanan tersebut agar produk iptek nuklir dapat bermanfaat, lebih dikenal dan diterima secara positif oleh masyarakat. Implementasi layanan inklusi sosial perlu dilakukan lebih dulu dengan mengidentifikasi kebutuhan layanan yang cocok sesuai dengan kondisi sumberdaya yang ada baik fisik perpustakaan, koleksi pustakawan dan produk iptek nuklir yang sesuai untuk ditransfer ilmunya kepada masyarakat. Pustakawan selaku pekerja pengetahuan (knowledge worker) harus membuat rencana yang matang untuk mengembangkan layanan tersebut agar memperoleh hasil yang optimal. Selain itu, pustakawan perlu secara aktif terlibat dalam jejaring antar perpustakaan lain, juga dengan peneliti yang menghasilkan produk litbangjirap. Hal ini agar kegiatan pemerdayaan masyarakat dengan media dan sarana yang dikelola perpustakaan dapat dilakukan terus-menerus dan melakukan pengembangan secara berkelanjutan. Pengembangan layanan terutama lebih mengedepankan layanan berbasis kebutuhan pengguna (on demand library services) serta tawaran kreatif para Pustakawan.

\section{DAFTAR PUSTAKA}

Badan Tenaga Nuklir Nasional. (2017). Deskripsi varietas unggul hasil pemuliaan mutasi padi, kedelai, kacang bijau, kapas, sorgum, gandum, kacang tanah. http://www.batan.go.id/index.php/id /publikasi/brosurleflet

Badan Tenaga Nuklir Nasional. (2018). Teknologi nuklir mampu tingkatkan produktivitas ternak. https://bit.ly/ 3DLifkY

Badan Tenaga Nuklir Nasional. (2020). Indonesia butuh banyak iradiator untuk sterilisasi produk kesehatan dan herbal. https://bit.ly/3yBl6Jm

Dadang. (2014). ITS luncurkan prototipe mesin cetak buruf braille. ITS News. https://www.its.ac.id/news/2014/10/ 08/its-luncurkan-prototipe-mesincetak-huruf-braille/

Haryanti, W. T. (2019). Transformasi perpustakaan berbasis inklusi sosial: implementasi pada perpustakaan khusus. Disampaikan pada Seminar disampaikan pada Seminar Nasional Peningkatan Peran Perpustakaan Khusus Berbasis Inklusi Sosial untuk Generasi Digital Indonesia. In Kompasiana. 
https://drive.google.com/drive/folder s/1wTUp2LTrIofDnP_D9fRNTin5v wRf_JhC

Kementerian Perencanaan Pembangunan Nasional Bappenas. (2018). Siaran Pers Seminar Nasional Literasi dan Pembangunan Nasional Sosial-Ekonomi.

Khairunisa. (2020). Strategi pengembangan perpustakaan berbasis inklusi sosial dalam upaya mewnjudkan masyarakat literate (skripsi).

http://repository.uinjambi.ac.id/4505/ 1/FILE SKRIPSI KHAIRUNISA $\%$ 2C S. IP.pdf

Mallawa, S. (2019). Transformasi perpustakaan berbasis inklusi sosial. In Kompasiana. https://bit.ly/2WQ9vt6

Marnelly, T. R. (2012). Corporate social responsibility (CSR): teori dan praktek di Indonesia. Jurnal Aplikasi Bisnis, 3(1), 49-59. https://jab.ejournal.unri.ac.id/ index.php/JAB/article/viewFile/910/ 903

Undang-undang Republik Indonesia Nomor 43 Tahun 2007 tentang perpustakaan, Undang-Undang Republik Indonesia (2007). https://www.perpusnas.go.id/ law-detail.php?lang=id\&id $=17092011$ 4322Ir9g6HhRuc

Noeraida. (2017). Penerapan SNI 7496:2009 di Perpustakaan PPIKSN BATAN (Issue November). http://reponkm.batan.go.id/6015/
Peraturan Kepala Perpustakaan Nasional Republik Indonesia Nomor 14 Tahun 2017 Tentang Standar Nasional Perpustakaan Khusus, (2017). https:// jdih.perpusnas.go.id/file_peraturan/ Perka_14_2017_SNP_Perpustakaan_ Khusus_Salinan.pdf

Rusmana, A. (2019). Peranan perpustakaan berbasis inklusi sosial di era digital. Seminar Nasional Perpustakaan Khusus Indonesia, 31 Juli 2019. https://drive.google. $\mathrm{com} /$ drive/folders/1wTUp2LTrIofD nP_D9fRNTin5vwRf_JhC

Sugiyono. (2012). Metode Penelitian Pendidikan Pendekatan Kuantitatif, Kualitatif dan R\&D | Perpustakaan Universitas Gresik. https:// digilib.unigres.ac.id/index.php ? $\mathrm{p}=$ show_detail\&id $=43$

Susanti, D. A. (2019). Implementasi Konsep Inklusi Sosial di Perguruan Tinggi; sebuah wacana. Media Pustakawan, 26(3), 224-232. https://ejournal. perpusnas.go.id/mp/article/view/543

Undang-Undang Republik Indonesia Nomor 43 Tahun 2007 tentang Perpustakaan, 3 (2007).

Utami, D., \& Prasetyo, W. D. (2019). Perpustakaan berbasis inklusi sosial untuk pembangunan Sosial-Ekonomi masyarakat. VISI PUSTAKA: Buletin Jaringan Informasi Antar Perpustakaan, 21(1), 31-38. https://ejournal. perpusnas.go.id/vp/article/view/74 